Kumawula, Vol. 3, No.2, Agustus 2020, Hal 174 - 188 DOI: https://doi.org/10.24198/kumawula.v3i2.25357

ISSN 2620-844X (online)

Tersedia online di http://jurnal.unpad.ac.id/kumawula/index

\title{
PENGEMBANGAN KAPASITAS PENGURUS KAMPUNG KB DALAM PENCATATAN DAN PENGOLAHAN DATA MIKRO KELUARGA
}

\author{
Sri Sulastri $^{{ }^{*}}$, Hetty Krisnani ${ }^{2}$, Eva Nuriyah Hidayat ${ }^{3}$ \\ 1,2,3 Departemen Kesejahteraan Sosial FISIP Universitas Padjadjaran \\ *sri.sulastri@unpad.ac.id
}

\begin{abstract}
ABSTRAK
Cakupan data keluarga di Kampung KB Dusun I Desa Pasireungit Kecamatan Paseh Kabupaten Sumedang masih belum cukup untuk menjangkau kelompok sasaran dan evaluasi program. Selain itu, metode pencatatan data masih dilakukan tanpa menggunakan alat bantu komputer, sehingga jika mereka harus memilah kelompok sasaran dengan kriteria tertentu, cukup merepotkan. Namun demikian, beberapa diantara pengurus Kampung KB dapat mengoperasikan aplikasi Microsoft Excel. Tujuan kegiatan pengabdian kepada masyarakat ini adalah untuk mengembangkan kapasitas pengurus Kampung KB dalam pencatatan dan pengolahan data mikro keluarga untuk penjangkauan kelompok sasaran layanan dan evaluasi program melalui kegiatan pelatihan. Materi yang disajikan meliputi pentingnya data yang cukup untuk mengidentifikasi kelompok sasaran layanan, mengevaluasi proses, dan mengevaluasi hasil; serta pengolahan data menggunakan program aplikasi komputer. Hasil dari kegiatan ini adalah peserta pelatihan memahami pentingnya data yang cukup untuk mengidentifikasi sasaran layanan dan evaluasi program. Peserta juga memahami cara pengkodean data, penggunaan kode dalam entry data, dan cara pengolahan data. Peserta pelatihan pengolahan data sudah cukup terampil walaupun kadang masih perlu dipandu. Untuk mendukung pencatatan dan pengolahan data keluarga, diperlukan fasilitas komputer. Pengurus Kampung KB perlu mendapatkan fasilitas ini.
\end{abstract}

Kata Kunci: Pengembangan Kapasitas Individu, Kampung KB, Pencatatan Data Mikro Keluarga, Pengolahan Data Mikro Keluarga, Manajemen Sistem Informasi

\section{CAPACITY BUILDING OF THE KAMPUNG KB MANAGEMENT IN THE RECORDING AND PROCESSING OF FAMILY MICRODATA}

\begin{abstract}
The coverage of family data in Kampung KB Dusun I Desa Pasireungit Kecamatan Paseh Kabupaten Sumedang is still not enough to reach the target groups and program evaluation. In addition, the method of recording data is still carried out without using computer aids, so if they have to sort out the target groups with certain criteria is quite troublesome. However, some of Kampung KB management can operate Microsoft Excel applications. The purpose of community service activities is to develop the capacity of the Kampung KB management in the recording and processing of family micro data for the outreach of target groups and program evaluation through training activity. The material presented in the training activities includes the importance of sufficient data to identify the target group of services, to evaluate the process, and to evaluate the results of the activities carried out; and data processing using computer application tools. The results of this activity are training participants understand the importance of sufficient data to identify service targets and for program
\end{abstract}


evaluation. They also understand how to encode data, use codes in data entry, and how to process data. The participants in the practice of data processing are already quite skilled although sometimes they still need to be guided. To support the recording and processing of family data, computer facilities are needed. Kampung KB management need to get this facility.

Keywords: Individual Capacity Building; Kampung KB; Family Micro Data Recording; Family Micro data Processing; Management Information System

\section{PENDAHULUAN}

Pembentukan Kampung Keluarga Berencana (KB) yang dicanangkan oleh Presiden Republik Indonesia pada tanggal 14 Januari 2016, terutama bertujuan untuk menggelorakan Program Kependudukan, Keluarga Berencana, dan Pembangunan Keluarga (KKBPK) agar keluarga dapat melaksanakan delapan fungsi keluarga dalam kehidupan sehari-hari. Delapan fungsi keluarga tersebut meliputi fungsi keagamaan, reproduksi, sosialisasi/pendidikan, ekonomi, perlindungan, kasih sayang, sosial budaya, dan pembinaan lingkungan. Kampung KB merupakan wilayah setingkat dusun atau RW yang memiliki kriteria jumlah keluarga miskin yang relatif lebih tinggi atau jumlah peserta KB yang relatif lebih rendah dari rata-rata tingkat Desa, dengan wilayah yang relatif terpencil. Kampung KB juga merupakan gerakan yang diprakarsai oleh masyarakat, oleh karena itu kegiatan operasional Kampung KB dilakukan oleh Pengurus Kampung KB yang berasal dari wilayah setempat. Struktur kepengurusan Kampung KB terdiri dari Pembina (Kepala Desa), Ketua, Sekretaris, Bendahara, dan pengurus delapan bidang yang masing-masing mengurus satu fungsi keluarga (BKKBN, 2017).

Kegiatan operasional di Kampung KB diawali dengan pendataan dan pemetaan keluarga. Pendataan Keluarga (PK) dilaksanakan secara serentak di seluruh wilayah Indonesia. Data anggota keluarga dikumpulkan dan dicatat oleh para kader yang telah dilatih pada lembar F/1/PK. Cakupan data meliputi data demografis anggota keluarga dan kondisi kesejahteraan keluarga. Data tersebut selanjutnya secara periodik dilakukan pemutahiran (Gambar 1). 


\section{Gambar 1. Cakupan Data pada Instrumen Pencatatan Data}

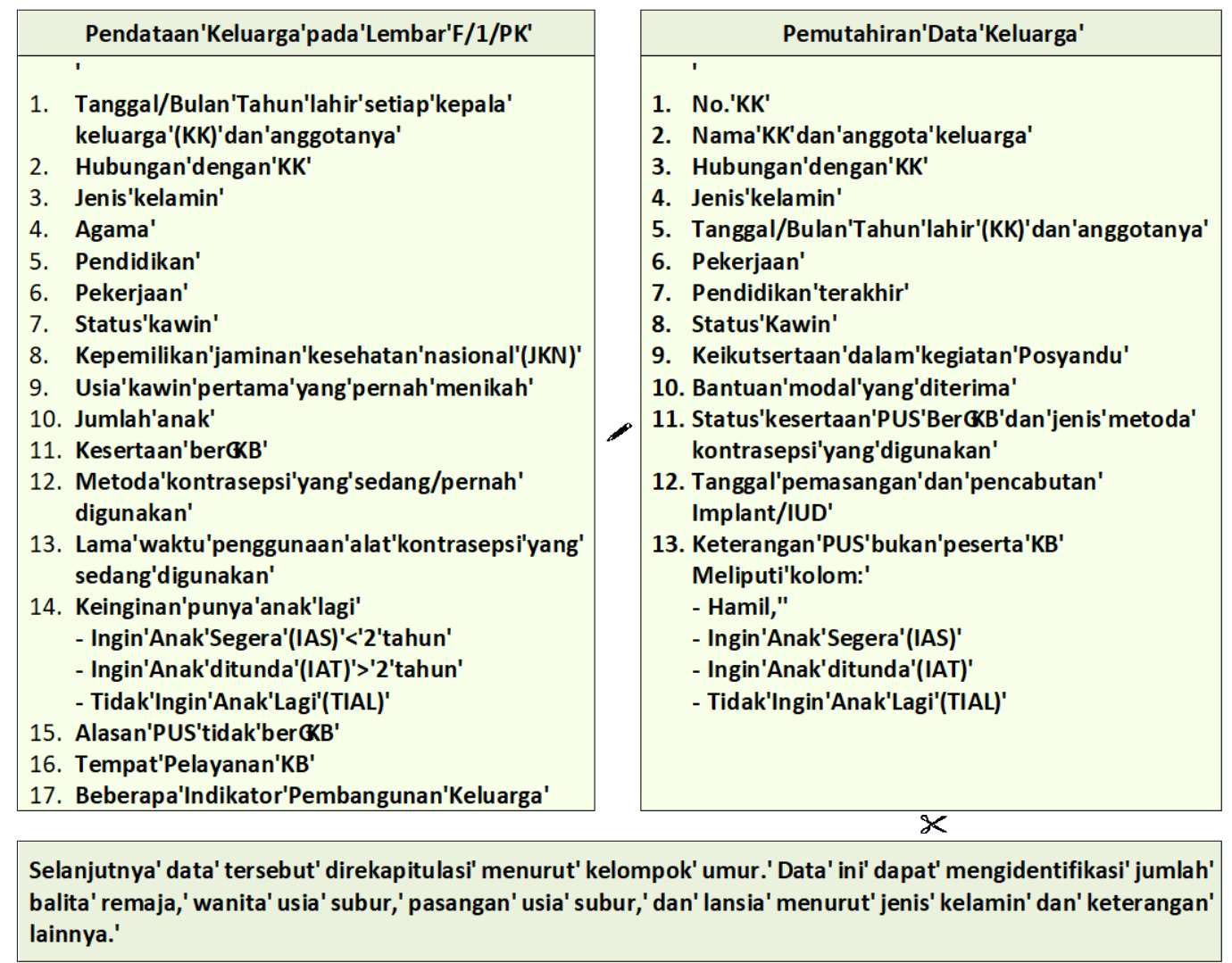

Sumber: BKKBN dan Buku Pencatatan Data Keluarga

Data individu anggota keluarga yang telah tercatat kemudian dipilah dan disajikan sebagai: a) Sasaran Pelayanan Kependudukan; b) Sasaran Pelayanan Program KB; c) Sasaran Pelayanan Program Ketahanan Keluarga; d) Sasaran Pelayanan pemberdayaan Ekonomi Keluarga; e) Sasaran Perbaikan Rumah Layak Huni; f) Sasaran Peningkatan Kesehatan Lingkungan; g) Sasaran Pencegahan Narkoba; dan lain-lain (Perwakilan BKKBN Provinsi Jawa Barat, 2018). Sebelum tahun 2015, pencatatan dan pemilahan data ini dilakukan tanpa menggunakan alat bantu komputer, tetapi mulai tahun 2015, data keluarga tersebut dicatat dengan menggunakan aplikasi microsoft excel oleh SKPD KB di tingkat kabupaten/kota, sehingga data ini dapat diolah dengan lebih mudah.

Di Kampung KB Dusun I Desa Pasireungit Kecamatan Paseh Kabupaten Sumedang, Pengurus Kampung KB dalam memahami permasalahan dan potensi di wilayahnya masih memanfaatkan data mikro keluarga hasil pencatatan tanpa menggunakan alat bantu komputer. Alasan yang dikemukakan adalah mereka merasa masih belum memiliki pengetahuan dan keterampilan pencatatan dan pengolahan data menggunakan aplikasi komputer. Para kader pengelola kegiatan melakukan pencatatan data "harian” pada buku catatan khusus menurut 
kelompok sasaran, meliputi buku catatan data keluarga yang memiliki anak balita, buku catatan data keluarga yang memiliki anak remaja, buku catatan data Pasangan Usia Subur dan Wanita Usia Subur (WUS), dan buku catatan data keluarga yang memiliki lansia. Proses pencatatan data ini dilakukan secara berjenjang mulai dari tingkat RT yang dikumpulkan oleh Kelompok Dasa Wisma jika ada penambahan atau pengurangan penduduk karena terjadinya peristiwa kelahiran, kematian, perpindahan, perceraian, atau perkawinan. Selanjutnya dilaporkan kepada pengelola kelompok kegiatan Bina Keluarga Balita (BKB), Bina Keluarga Remaja (BKR), Bina Keluarga Lansia (BKL) dan pengelola kegiatan pembinaan PUS dan WUS. Cakupan data yang terhimpun pada buku cacatan tersebut seperti tertera pada Tabel 1.

Tabel 1

\section{Cakupan Data untuk Pengelolaan Kelompok Kegiatan Di Kampung KB Dusun I Pasireungit}

\begin{tabular}{|c|c|c|c|}
\hline $\begin{array}{c}\text { Cakupan'Data" } \\
\text { untuk'Kegiatan'BKB' }\end{array}$ & $\begin{array}{c}\text { Cakupan'Data" } \\
\text { untuk'Kegiatan'BKR! }\end{array}$ & $\begin{array}{c}\text { Cakupan'Data'untuk' } \\
\text { Pembinaan'WUS'dan'PUS! }\end{array}$ & $\begin{array}{c}\text { Cakupan'Data" } \\
\text { untuk'Kegiatan'BKL! }\end{array}$ \\
\hline $\begin{array}{l}\text { 1. Nama'anak' } \\
\text { 2. Tanggal/bulan/'tahun' } \\
\text { lahir' } \\
\text { 3. Nama'Ayah' } \\
\text { 4. Nama'lbu' } \\
\text { 5. Alamat'RT/RW'(Dasa' } \\
\text { Wisma)' } \\
\text { 6. Hasil'pencatatGn'data' } \\
\text { di'Posyandu'per'bulan' } \\
\text { Catatan:\& } \\
\text { Pencatan\&ipilah\& } \\
\text { berdasarkan\&elompok\& } \\
\text { umur\&万\&ulan,871\& } \\
\text { bulan,\&2723\&ulan,\&an\& } \\
\text { 2470\&ulan.\& }\end{array}$ & $\begin{array}{l}\text { 1. Nama'Ayah' } \\
\text { 2. Nama'Ibu' } \\
\text { 3. Nama'remaja' } \\
\text { 4. Umur'remaja'(15G5' } \\
\text { tahun'belum' } \\
\text { menikah)' } \\
\text { 5. Alat'kontrasepsi' } \\
\text { yang'digunakan' } \\
\text { orangtua' } \\
\text { 6. Alamat'RT/RW' } \\
\text { 7. Pendidikan'remaja' } \\
\text { 8. Keaktifan'daGam' } \\
\text { kegiatan'remaja' } \\
\text { ! }\end{array}$ & $\begin{array}{l}\text { 1. Nama'wanita' } \\
\text { 2. Tanggal/bulan/'tahun' } \\
\text { lahir' } \\
\text { 3. Nama'Suami'bagi'PUS' } \\
\text { 4. Tahapan'KS' } \\
\text { 5. Alat'kontrasepsi'yang' } \\
\text { digunakan' } \\
\text { 6. Kepemilikan'jaminan' } \\
\text { kesehatan' } \\
\text { 7. Alamat'RT/RW' } \\
\text { Catatan:\& } \\
\text { Pencatan\&ata\&NUS\&an\& } \\
\text { PUS\&icampurkan! }\end{array}$ & $\begin{array}{l}\text { 1. Nama'keluarga'memiliki' } \\
\text { lansia'(suamiGsteri)' } \\
\text { 2. Nama'Lansia' } \\
\text { 3. Umur'lansia'(50+)' } \\
\text { 4. Alamat'RT/RW' } \\
\text { 5. Tahapan'KS' } \\
\text { 6. Status'PUS'untuk' } \\
\text { keluarga'lansia' } \\
\text { 7. Kesertaan'berCKB'untuk' } \\
\text { keluarga'berstatus'PUS' } \\
\text { 8. Kepemilikan'jaminan' } \\
\text { kesehatan' } \\
\text { 9. Keaktifan'keluarga'lansia' } \\
\text { dalam'kegiatan'BKL' } \\
\text { 10. Keaktifan'lansia'dalam' } \\
\text { kegiatan'lansia! }\end{array}$ \\
\hline
\end{tabular}

Sumber : Buku Pencacatan Data Balita, Remaja, WUS dan PUS, dan Lansia di Kampung KB Dusun I Desa Pasireungit

Merujuk pada dokumen Perencanaan Kegiatan di Kampung KB Dusun I Pasireungit, terdapat beberapa kegiatan yang direncanakan oleh setiap Bidang Kepengurusan Kampung KB memiliki kelompok sasaran yang sama (Gambar 2). Namun demikian, walaupun kelompok sasarannya sama, misalnya remaja, karakteristik kelompok sasaran remaja untuk bidang reproduksi berbeda dengan untuk bidang ekonomi, demikian juga untuk bidang lainnya. Untuk menjangkau kelompok sasaran tersebut, tentu diperlukan cakupan data yang memadai. Cakupan data yang tercatat pada buku data saat ini (Tabel 1) belum cukup untuk mengidentifikasi kelompok sasaran tersebut. Selain masalah kecukupan data yang masih kurang selaras dengan kebutuhan penjangkauan kelompok sasaran, cara pencatatannya pun masih menggunakan buku catatan, belum menggunakan alat bantu komputer, sehingga kalaupun cakupan datanya cukup maka akan mengalami kesulitan jika harus memilah 
menurut karakteristik kelompok sasaran yang diinginkan. Cara pencatatan data seperti ini tampaknya masih terjadi di sebagian besar Kampung KB di Provinsi Jawa Barat (Sulastri, dkk. 2019). Kecukupan data tidak hanya diperlukan untuk penjangkauan kelompok sasaran layanan tetapi penting juga untuk evaluasi proses maupun evaluasi hasil dari kegiatan yang dilakukan. Masalah kecukupan data ini tampaknya ada kaitan dengan dokumen Perencanaan Kegiatan di Kampung KB ini yang belum mencantumkan indikator proses maupun indikator hasil, sehingga belum dapat ditentukan data apa yang harus tercakup dalam pencatatan data.

\section{Gambar 2. Kelompok Sasaran Kegiatan Kampung KB Dusun I Desa Pasireungit}

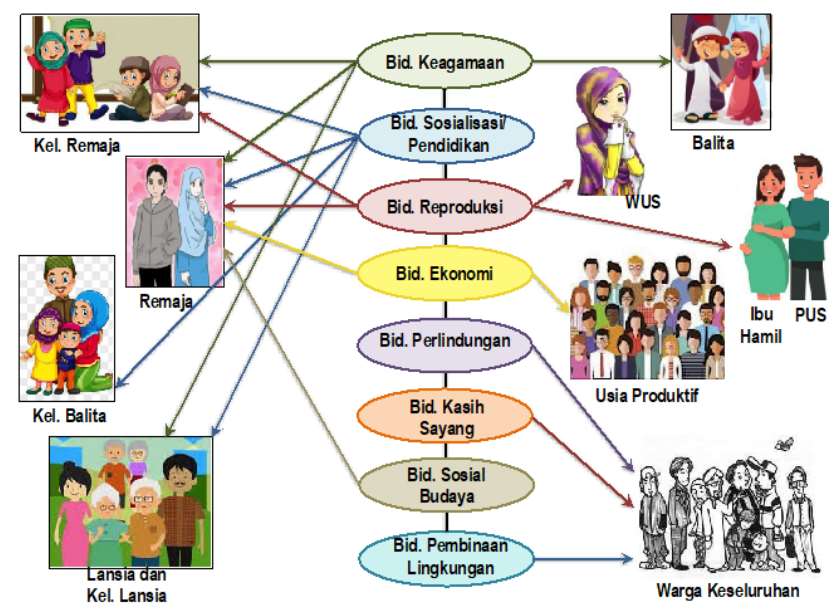

Sumber: Diolah dari Dokumen Rencana Kegiatan 2018

Berdasarkan hasil perbincangan dengan Pengurus Kampung KB, mereka ingin memiliki pengetahuan dan keterampilan pencatatan dan pengolahan data dengan menggunakan aplikasi komputer. Diantara mereka, ada beberapa orang yang sudah bisa mengoperasikan aplikasi microsoft excel tetapi belum pernah menggunakannya untuk kebutuhan pencatatan dan pengolahan data penduduk. Oleh karena itu, dalam kegiatan Pengabdian Pada Masyarakat (PPM) yang terintegrasi dengan kegiatan riset ini, dilakukan kegiatan Pengembangan Kapasitas Pengurus Kampung KB dalam Pencatatan dan Pengolahan Data Keluarga.

\section{METODE}

Terkait dengan temuan masalah di Kampung KB Dusun I Desa Pasireungit, kerangka pemecahan masalah yang digunakan dalam kegiatan PPM ini yaitu dengan cara mengembangkan kapasitas pengurus Kampung KB dalam pencatatan dan pengolahan data keluarga. Setiap bidang dalam struktur kepengurusan Kampung KB memerlukan dukungan data kelompok sasaran untuk menjangkau kelompok sasarannya. Selain itu, dukungan data ini 
diperlukan pula untuk keperluan evaluasi program, baik evaluasi proses maupun evaluasi hasil (Gambar 3).

\section{Gambar 3. Kerangka Pemecahan Masalah}

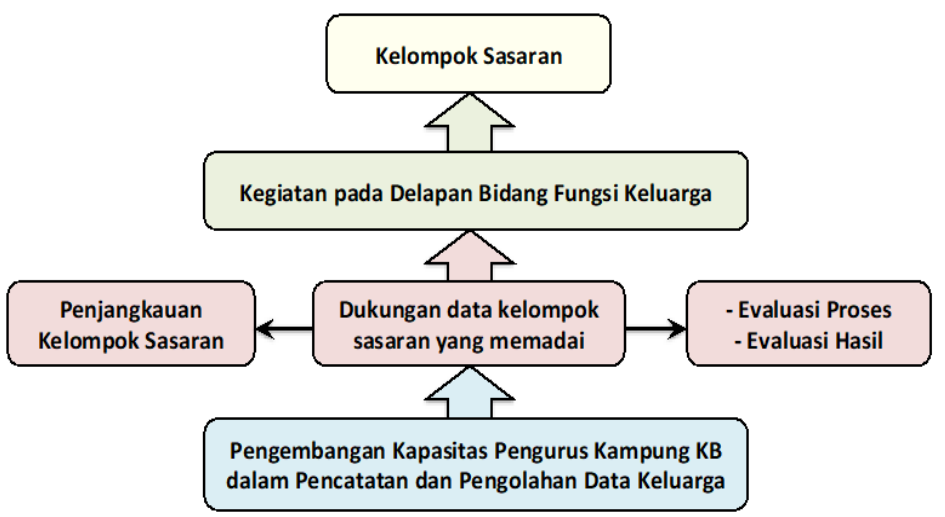

Pengurus Kampung KB terdiri atas Ketua, Sekretaris, Bendahara, dan seluruh pemegang jabatan Bidang Kegiatan terlibat langsung dalam proses perencanaan maupun pelaksanaan kegiatan di Kampung KB. Mereka yang seyogyanya menentukan kriteria kelompok sasaran, indikator proses, dan indikator hasil dalam dokumen perencanaan kegiatannya. Walaupun sebagian besar dari mereka tidak memiliki pengetahuan dan keterampilan dalam mengoperasikan komputer, tetapi mereka setidaknya harus mengetahui data apa yang mereka perlukan untuk mengidentifikasi kelompok yang ingin disasarnya.

Pengembangan kapasitas pengurus Kampung KB ini dilakukan melalui kegiatan pelatihan. Tahapan kegiatan yang dilakukan mengikuti model tahapan kegiatan pelatihan ADDIE yang merupakan akronim dari Assess and analyze needs, icipepevelop learning objectives, Design and develop the program, Implementation the design, dan Evaluate performance (Biech, 2005:39).

Pada tahap Assess and analyse need, tim PPM memastikan masalah dan potensi yang dimiliki pengurus Kampung KB serta kebutuhan pemecahan masalah tersebut. Hasil dari kegiatan ini telah dipaparkan pada bagian pendahuluan yang menjadi latar belakang kegiatan PPM ini, bahwa di Kampung KB Dusun I Desa Pasireungit terdapat masalah: 1) cakupan data masih kurang selaras dengan kebutuhan identifikasi kelompok sasaran layanan; 2) pencatatan data masih belum menggunakan alat bantu komputer; 3) dalam dokumen Perencanaan Kegiatan belum ditentukan indikator proses dan indikator hasil sehingga belum dapat ditentukan data apa yang harus tercakup dalam pencatatan data, selain itu dalam beberapa 
kegiatan belum ditentukan kelompok sasaran secara spesifik. Masalah yang ditemukan dalam proses pencatatan dan pengolahan data ini terkait dengan masih kurangnya pemahaman tentang hubungan antara proses perencanaan dengan pencatatan dan pengolahan data, dalam hal ini data keluarga. Namun demikian, terdapat potensi sumber daya manusia yang memiliki keterampilan mengoperasikan aplikasi komputer microsoft excel yang dapat digunakan untuk pencatatan dan pengolahan data penduduk atau anggota keluarga.

Pada tahap develop learning objectives, tim PPM menentuan tujuan pelatihan yaitu untuk meningkatkan pemahaman pengurus Kampung KB tentang pentingnya kecukupan data untuk penjangkauan kelompok sasaran layanan dan untuk mengevaluasi proses dan hasil dari kegiatan yang dilaksanakan; serta untuk memberikan pengetahuan dan keterampilan tentang pengolahan data dengan menggunakan alat bantu komputer.

Untuk mewujudkan tujuan ini, tim PPM melakukan sosialisasi kegiatan kepada Ketua Kampung KB dan Tenaga Penggerak Desa (TPD) yang bertugas sebagai pembina Kampung KB dan juga merangkap jabatan sebagai Sekretaris pada struktur kepengurusan Kampung KB Dusun I Desa Pasireungit. Pertemuan ini untuk memastikan bahwa kegiatan pelatihan ini diperlukan oleh pengurus Kampung KB. Tim pelaksana juga menemui pihak Desa Pasireungit untuk mendapatkan ijin melakukan kegiatan di wilayah kerjanya; sekaligus juga mendapatkan dukungan fasilitas ruangan.

Pada tahap design and develop the program, tim PPM merancang materi pelatihan sesuai dengan kebutuhan pengetahuan dan keterampilan yang diperlukan oleh peserta. Dalam hal ini menggunakan pendekatan model deduktif, yakni penyusunan materi pelatihan didasarkan pada hasil identifikasi kebutuhan pelatihan secara umum untuk kelompok sasaran yang mempunyai ciri yang sama (Kamil, 2010). Secara umum, pengurus Kampung KB memiliki pengetahuan dan keterampilan yang relatif sama di dalam proses perencanaan, proses pencatatan data, dan pengolahan data. Namun demikian diantaranya ada tiga orang yang sudah memiliki keterampilan untuk mengoperasikan aplikasi komputer microsoft excel tetapi belum pernah menggunakannya untuk pencatatan dan pengolahan data keluarga. Untuk ketiga orang tersebut, pada kegiatan PPM ini akan diberikan pula materi tentang proses pencatatan dan pengolahan data keluarga menggunakan aplikasi komputer microsoft excel.

Materi yang disajikan meliputi: 1) Pentingnya kecukupan data untuk penjangkauan kelompok sasaran layanan, mengevaluasi proses dan hasil dari kegiatan yang dilaksanakan; serta keterkaitan kecukupan data tersebut dengan perumusan rencana kegiatan. 2) Proses 
pencatatan dan pengolahan data dengan menggunakan alat bantu aplikasi komputer, meliputi proses koding, memasukkan data pada komputer (entry data), dan pengolahan data untuk kebutuhan penyediaan data kelompok sasaran layanan dan evaluasi, sambil mencoba mempraktikkannya.

Pada tahap implementation the design, jadwal kegiatan ditentukan atas kesepakatan bersama antara tim PPM, peserta pelatihan, dan pihak Desa setempat yang memberikan fasilitas ruangan. Pelatihan dilaksanakan dalam dua kali pertemuan. Pertemuan pertama mencakup materi pentingnya kecukupan data dalam mengidentifikasi kelompok sasaran layanan dan evaluasi, serta keterkaitan kecukupan data dengan rumusan rencana kegiatan Kampung KB. Kegiatan pelatihan ini diikuti oleh seluruh pengurus Kampung KB terutama Pengurus delapan Bidang Kegiatan. Bahan rujukan yang digunakan adalah Rencana Kegiatan Kampung KB Tahun 2019 yang telah mereka rumuskan yang berisi tentang uraian kegiatan, waktu, lokasi, sasaran, dan hasil yang diharapkan. Bahan rujukan lainnya adalah buku pencatatan data keluarga balita, keluarga remaja, WUS dan PUS, dan keluarga lansia (Tabel 1).

Dengan merujuk pada kedua dokumen yang mereka miliki tersebut, peserta pelatihan diajak berdiskusi tentang keterkaitan antara rumusan Rencana Kegiatan Tahunan dengan pentingnya kecukupan data. Karakteristik kelompok sasaran yang diperlukan setiap bidang kegiatan relatif berbeda, oleh karena itu pada Rencana Kegiatan perlu dijelaskan secara rinci. Karakteristik kelompok sasaran tersebut akan menjadi rujukan dalam penyediaan datanya.

Karakteristik kelompok sasaran remaja untuk kegiatan Bidang Reproduksi berbeda dengan untuk kegiatan Bidang Ekonomi. Demikian juga dengan kelompok sasaran PUS, tidak semua PUS memerlukan metoda kontrasepsi, oleh karena itu tidak semua PUS harus menjadi kelompok sasaran layanan Bidang Reproduksi. Kelompok sasaran utama Bidang Reproduksi adalah PUS yang tidak menggunakan metoda kontrasepsi tetapi sebenarnya memerlukannya. Mereka adalah yang memiliki risiko tinggi jika hamil dan melahirkan, yaitu yang masuk kedalam kategori "empat terlalu” yaitu terlalu tua, terlalu muda, terlalu sering melahirkan, dan terlalu rapat jarak kelahirannya. PUS yang ingin menunda kehamilan atau menghentikan kehamilan (tidak ingin memiliki anak lagi) tetapi tidak menggunakan metoda kontrasepsi juga merupakan kelompok sasaran utama Bidang Reproduksi. Mereka termasuk dalam kategori yang kebutuhan KBnya tidak terpenuhi (unmet need KB). Demikian juga untuk kebutuhan Bidang Perlindungan, misalnya ingin memberi layanan perlindungan bagi anak melalui 
kepemilikan Kartu Identitas Anak (KIA), perlu ditambahkan data kepemilikan KIA tersebut pada data belita dan remaja yang berumur kurang dari 17 tahun.

Ketersediaan data untuk penjangkauan kelompok sasaran harus selaras dengan karakteristik kelompok sasaran yang telah ditentukan dalam Rencanaan Kegiatan. Untuk melengkapi data tersebut diperlukan masukan dari Pengurus Bidang Kegiatan tentang cakupan data yang diperlukan oleh masing-masing bidang, selaras dengan rencana kegiatannya. Selanjutnya dirembugkan bagaimana data tersebut dikumpulkan.

Pada pertemuan pertama ini dibahas juga perlunya penentuan indikator proses dan indikator hasil yang ingin dicapai dari setiap kegiatan, karena akan berkaitan juga dengan penyediaan data untuk kebutuhan mengevaluasinya. Salah satu contoh yang ditunjukkan adalah pada kegiatan Bina Keluarga Lansia yang direncanakan oleh Bidang Pendidikan dan Sosialisasi, terdapat kegiatan Pemeriksaan Lansia Rutin dengan kelompok sasaran lansia. Hasil yang diharapkan adalah terkontrolnya perkembangan kesehatan lansia. Terkait dengan hasil yang diharapkan tersebut di dalam rumusan perencanaan kegiatan belum ada indikator proses dan indikator hasilnya. Indikator prosesnya misalnya kehadiran lansia pada kegiatan pemeriksaan rutin. Capaian proses kegiatan ini dapat dilihat melalui data proporsi kehadiran lansia pada kegiatan pemeriksaan rutin. Indikator hasilnya misalnya hasil pemeriksaan serta jumlah dan proporsi lansia yang terdeteksi memiliki kesehatan baik, rentan, dan sebagainya. Data ini dapat digunakan untuk kebutuhan evaluasi dan rencana tindak lanjut berikutnya.

Pertemuan kedua menyajikan materi proses pengolahan data dengan menggunakan alat bantu aplikasi komputer. Peserta pelatihan diberi pemahaman tentang koding data, cara memasukkan data pada komputer (entry data), dan pengolahan data untuk kebutuhan penyediaan kelompok sasaran dan evaluasi. Penyajian materi ini masih diikuti oleh semua peserta pelatihan pertemuan sebelumnya. Pemahaman tentang koding data berguna untuk seluruh peserta pelatihan karena nantinya mereka dapat berperan membantu koding data. Peserta pelatihan diberikan pemahaman tentang apa yang dimaksud dengan koding data dan kegunaannya dalam proses entry dan pengolahan data ketika akan mengolah data tersebut menggunakan aplikasi komputer. Semua peserta pelatihan dapat melihat contoh penggunaan koding data pada hasil entry data (data sheet) yang telah disiapkan tim PPM sebelum kegiatan pelatihan dilaksanakan. Kegiatan entry data ini dilakukan oleh tim PPM agar lebih dapat mempersingkat waktu. 
Kegiatan dilanjutkan dengan penyajian materi pelatihan pengolahan data. Peserta pelatihan utama adalah tiga orang peserta yang telah memiliki keterampilan mengoperasikan komputer khususnya mengoperasikan aplikasi komputer microsoft excel. Sementara peserta lainnya diminta untuk memberikan informasi kebutuhan hasil olah data, sebagai bahan untuk tugas yang harus dilakukan oleh ketiga peserta. Untuk sementara, hasil olah data yang diminta hanya yang dapat dihasilkan dari data yang tercakup pada data sheet sesuai yang tercantum pada Tabel 1.

Pada saat kegiatan pelatihan berlangsung, peserta pelatihan dapat menggunakan laptop yang disediakan oleh tim pelaksana, tetapi untuk berlatih di rumah, peserta melakukannya dengan fasilitas laptop sendiri. Kampung KB belum memiliki sarana komputer. Hal ini menjadi kendala dalam pencatatan data dengan alat bantu komputer di Kampung KB Dusun I Desa Pasireungit.

\section{Gambar 4a. Suasana Latihan Pencatatan Data}

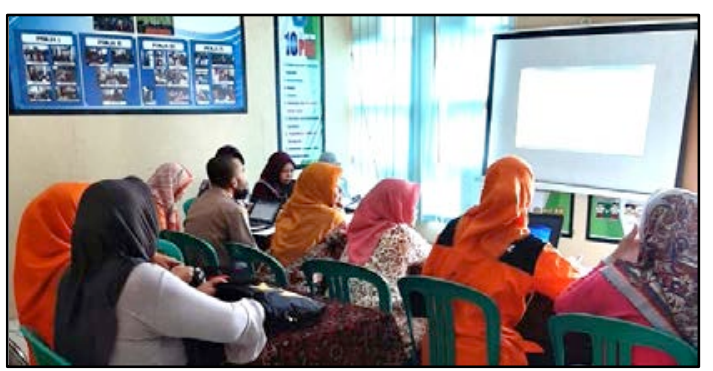

\section{Gambar 4b. Suasana Latihan Pengolahan Data}

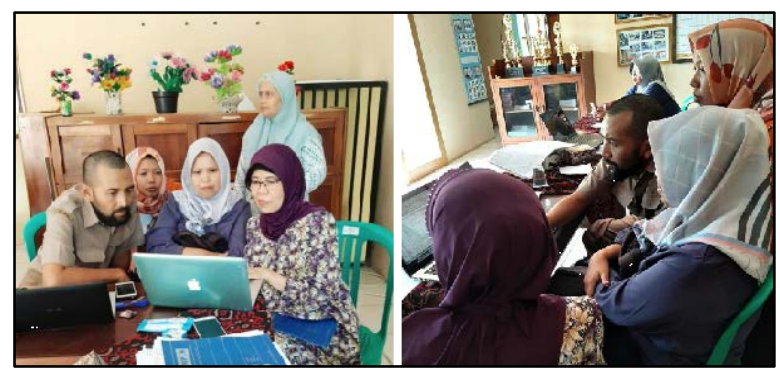

Tahap berikutnya yaitu tahap evaluate performance. Penilaian pemahaman peserta pelatihan tentang kecukupan data dilakukan dengan cara mengajak peserta untuk menyebutkan data yang diperlukan ketika ingin mengidentifikasi kelompok sasaran tertentu, misalnya untuk mengidentifikasi remaja yang sudah tidak sekolah, anak yang belum memiliki akte kelahiran, anak yang belum memiliki kartu identitas anak, PUS unmet need KB, dan sebagainya. 
Penilaian keterampilan peserta dalam mengolah data menggunakan alat bantu komputer, selain melalui pengamatan pada saat kegiatan pelatihan berlangsung, dilakukan pula melalui penugasan yang dikirim secara daring untuk memastikan bahwa tiga orang peserta pelatihan ini terus berupaya mempraktikkan keterampilannya. Dalam lembar penugasan tersebut ketiga orang peserta pelatihan diminta untuk mengirimkan hasil olah data kelompok sasaran dengan kriteria tertentu menurut wilayah RT, dan menyediakan data makronya. Sebagai contoh, mereka diminta untuk menyajikan data mikro remaja yaitu berupa daftar nama dan alamat yang dikelompokkan menurut wilayah RT, yang di dalamnya terdapat data umur, jenjang pendidikan yang ditamatkan, masih sekolah atau tidak, dan bekerja atau tidak. Contoh lain, peserta diminta untuk menyajikan data mikro penduduk pra lansia dan lansia menurut wilayah RT domisilinya; data umur diurutkan dari yang muda ke yang tua. Peserta juga diminta untuk menyajikan data mikro Wanita Usia Subur yang akan dijadikan sebagai kelompok sasaran kegiatan untuk tujuan peningkatan usia kawin.

\section{HASIL DAN PEMBAHASAN}

Hasil evaluasi kegiatan pelatihan materi pertama yaitu tentang pentingnya kecukupan data untuk penjangkauan kelompok sasaran layanan, mengevaluasi proses dan hasil dari kegiatan yang dilaksanakan; serta keterkaitan kecukupan data tersebut dengan perumusan rencana kegiatan melalui proses diskusi, peserta pelatihan memahami pentingnya kecukupan data dalam pencatatan data kelompok sasaran. Mereka dapat menyebutkan kebutuhan data ketika ingin menjaring kelompok sasaran tertentu; misalnya untuk mengetahui balita yang belum memiliki akte kelahiran, atau untuk mengetahui anak usia kurang dari 17 tahun yang belum memiliki Kartu Identitas Anak (KIA), dan untuk mengetahui PUS yang kebutuhan KBnya tidak terpenuhi (unmet need KB). Beberapa data sebenarnya ada yang sudah tercakup dalam data hasil pendataan keluarga dengan menggunakan formulir F/1/PK, dan mereka sendiri terlibat dalam pengumpulan data tersebut, tetapi ada beberapa data yang perlu ditambahkan. Oleh karena cakupan data bertambah maka pencatatan data akan lebih baik jika dilakukan menggunakan alat bantu komputer.

Hasil kegiatan pelatihan melalui penjelasan materi pengolahan data, peserta pelatihan mengetahui apa yang dimaksud dengan koding data, penggunaannya dalam proses entry data, dan kegunaannya dalam pengolahan data. Pengetahuan ini diperoleh dari contoh format hasil entry data yang digunakan untuk pengolahan data dengan menggunakan aplikasi komputer. Dari pemahaman ini diharapkan seluruh peserta pelatihan setidaknya dapat berperan dalam 
proses koding data. Tiga peserta yang mengikuti praktik pengolahan data dapat mengerjakan tugas untuk menghasilkan hasil olah data yang diharapkan, walaupun terkadang masih perlu dipandu; tetapi komunikasi diantara tim PPM dan peserta pelatihan berjalan lancar karena terbantu oleh alat komunikasi.

Terkait dengan pentingnya pencatatan data yang memadai dan pengolahannya bagi institusi yang memberikan pelayanan sosial, Kettner menyebutkan bahwa data dan informasi dalam pelayanan sosial sangat penting, oleh karena itu, para pengelola lembaga layanan sosial banyak yang mengupayakan pengumpulan data untuk membantu proses layanan dan untuk melihat output dari klien yang mereka layani. Ketika data dan informasi tersedia dengan cukup maka upaya intervensi dapat disempurnakan. Para manajer dan administrator lembaga layanan sosial berkewajiban memastikan bahwa sistem informasi dirancang sedemikian rupa sehingga akan menghasilkan informasi yang bermanfaat. Hal ini menjadi bagian dari fungsi perencanaan (Kettner, 2002).

Terkait dengan proses perancangan sistem informasi, Lewis et al. (1991) menyatakan bahwa terdapat sepuluh pertanyaan yang harus dijawab dalam proses perencanaan, tiga diantaranya adalah: Hasil apa yang paling penting bagi klien yang akan terpengaruh oleh program? Langkah apa yang perlu dilakukan untuk memenuhi setiap tujuan? dan Bagaimana keberhasilan program dievaluasi? (hlm. 8). Data yang diperlukan untuk evaluasi dapat diidentifikasi melalui pemeriksaan kriteria yang tercantum sebagai bagian dari proses perencanaan. Setiap kriteria menunjukkan jalan menuju informasi yang akan dibutuhkan untuk menilai kemajuan lembaga dalam memenuhi standar yang diinginkan. Pada saat proses perencanaan dilaksanakan harus mempertimbangkan juga metode yang akan digunakan untuk mengevaluasi keberhasilan layanan (hlm. 26). Penentuan tujuan atau sasaran atau target yang diidentifikasi sebagai bagian dari proses perencanaan juga memberikan dasar untuk evaluasi hasil program. Dengan demikian, pada titik ini kriteria evaluasi telah diidentifikasi. Jika perencana juga menggunakan peluang ini untuk merencanakan pengumpulan data yang relevan secara berkelanjutan, evaluasi yang efektif dapat menjadi kenyataan (hlm. 54).

Merujuk pada kedua literatur tersebut, maka pada saat proses perencanaan seyogyanya sudah ditentukan: karakteristik kelompok sasaran yang akan dilayani atau diintervensi; hasil yang ingin dicapai (indikator hasil untuk evaluasi hasil); langkah-langkah yang dilakukan (indikator proses untuk kegiatan monitoring), rancangan evaluasi proses, dan rancangan evaluasi hasil. Karakteristik kelompok sasaran, indikator proses, dan indikator hasil tersebut 
merupakan input data yang masuk pada sistem informasi. Pencatatan dan pengolahannya disesuaikan dengan karakteristik kelompok sasaran dari setiap program atau kegiatan, rancangan evaluasi proses, atau rancangan evaluasi hasil. Hal ini yang seyogyanya dilakukan oleh para pengelola lembaga atau institusi yang memberikan layanan sosial, termasuk Pengurus Kampung KB. Pengelolaan sistem informasi memerlukan perhatian khusus. Para pengelola harus menyediakan data sesuai dengan kebutuhan lembaga pelayanan pada saat diperlukan. Dengan demikian seyogyanya dikelola oleh unit kerja khusus.

Dalam struktur kepengurusan Kampung KB belum ada deskripsi tugas pencatatan dan pengolahan data dan siapa petugasnya. Hal ini dapat mengakibatkan pada tidak adanya unit kerja yang bertanggung jawab atas ketersediaan data yang sangat diperlukan dalam proses layanan Kampung KB. Padahal sejak tahun 2018, BKKBN sudah mencanangkan program Rumah Dataku untuk mendukung pelaksanaan kegiatan Kampung KB. Kondisi ini tampaknya terjadi di sebagian besar di Kampung KB di Provinsi Jawa Barat karena struktur organisasi yang dibentuk relatif seragam (Sulastri. 2019). Oleh karena kegiatan pencatatan data ini mendukung seluruh bidang, seyogyanya dipegang oleh unit kerja khusus, atau bisa juga menjadi bagian dari tugas sekretaris yang didukung oleh beberapa orang staf. Dukungan sarana komputer diperlukan untuk pencatatan data maupun untuk pengolahan data. Selayaknya Pengurus Kampung KB mendapatkan fasiltas ini. Semoga pihak-pihak yang memiliki sumberdaya untuk mengadakan sarana ini dapat menyediakannya.

\section{SIMPULAN}

Berbasis pada indikator tujuan yang ingin dicapai kegiatan PPM ini maka dapat dikatakan bahwa terdapat peningkatan pemahaman pengurus Kampung KB Dusun I Desa Pasireungit tentang kebutuhan kecukupan data untuk mengidentifikasi kelompok sasaran layanan. Kecukupan data ini berguna untuk penjangkauan kelompok sasaran dan evaluasi program. Demikian juga keterampilan pengolahan data dengan menggunakan aplikasi komputer microsoft excel, sedikitnya sudah difahami kepentingannya. Untuk meningkatkan keterampilan apapun perlu terus berlatih. Kami Tim PPM berharap agar ketiga peserta pelatihan ini terus berlatih baik secara berkelompok maupun secara mandiri. Kami siap membantu walaupun secara daring. Kapasitas ini dapat menjadi bekal dalam mendukung layanan Kampung KB agar semua kelompok sasaran spesifik dari setiap kegiatan yang dilaksanakan dapat terjangkau; dan semua kegiatan dapat dievaluasi, baik proses maupun hasil capaiannya. 


\section{UCAPAN TERIMAKASIH}

Pada kesempatan ini kami mengucapkan terimakasih kepada Rektor Universitas Padjadjaran, DRPMI Universitas Padjadjaran dan jajaran terkait, Dekan FISIP, Manager Riset dan Kerjasama FISIP dan Staf, Kepala Departemen Kesejahteraan Sosial, Dinas Pengendalian Penduduk dan Keluarga Berencana Kabupaten Sumedang, Kepala Desa Pasireungit Kecamatan Paseh, Pengurus Kampung KB Dusun I Desa Pasireungit, yang telah memberikan dukungan dana, ijin pelaksanaan kegiatan, dan fasilitasi tempat pelaksanaan kegiatan pelatihan. Ucapan terimakasih kami sampaikan pula kepada semua pihak yang telah membantu, terutama kepada Reviewer dan Redaksi Jurnal Kumawula yang telah menelaah, memberi masukan, dan menerbitkan artikel ini. Akhirnya kami berharap agar kegiatan ini dapat menambah pengetahuan, pemahaman, keterampilan dalam pencatatan dan pengolahan data untuk mendukung pelayanan sosial, khususnya di Kampung KB Dusun I Desa Pasireungit.

\section{DAFTAR PUSTAKA}

Acehportal.com. (2018, 14 Maret). BKKBN Akan Programkan Rumah Dataku di Setiap Kampung KB. https://www.acehportal.com/2018/03/14/bkkbn-akan-programkanrumah-dataku-di-setiap-kampung-kb/

Biech, E. 2005. Training For Dummies. Indianapolis, Indiana: Wiley Publishing, Inc.

BKKBN. 2017. Pedoman Pengelolaan Kampung KB: Pedoman bagi Pengelola Kampung KB di Lini Lapangan. Jakarta: BKKBN.

BKKBN Perwakilan Provinsi Jawa Barat. 2018. Bina Kampung KB: Panduan Teknis Pelaksanaan Pembinaan Kampung KB.

Chaskin, R.J., Brown, P., Venlzatesh, S., Vidal, A. 2001. Building Community Capacity. New York: Aldine de Gruyer.

Clark, D. 2015. History of the ADDIE Model.

(http://www.nwlink.com/ donclark/history_isd/addie.html, diakses 13 September 2019)

Kamil, Mustofa. 2010. Model-Model Pelatihan.

(http://kamilunkamil.blogspot.com/2010/03/model-model-pelatihan.html?m=1, diakses 20 April 2016) 
Kettner, P.M. 2002. Achieving Excellence in the Management of Human Service Organization. Boston, London, Toronto, Sydney, Tokyo, Singapore : Allyn and Bacon.

Lewis, J.A., Lewis M.D., Souflee, F. 1991. Management of Human Service Programs. California: Brooks/Cole Publishing Company.

Ramadhani, W.S. dan Sulastri, S. Analisis Sistem Informasi Manajemen di Yayasan Mizan Amanah.

(https://www.academia.edu/36264047/SISTEM_INFORMASI_MANAJEMEN_DI_ YAYASAN_MIZAN_AMANAH diakses 22 Juli 2019)

Sulastri, S., Krisnani, H., Sari, D.P., Ekawati, R. 2019. "Penanganan Unmet Need KB di Kampung KB: Studi Kasus di Dua Kampung KB di Kabupaten Cianjur”. Jurnal Kependudukan Indonesia Vol. 14, No. 2, Desember 2019: 